Volume 7, Issue 12, December 2019

DOI: $\underline{\text { https://doi.org/10.24113/ijellh.v7i12.10240 }}$

\title{
Grotowski’s Poor Theatre: An Experiment in Theatre
}

Dr. Bipin Chandra Uniyal,

Assistant Professor English

Head Dept. of English

Bal Ganga Degree College Sendul, Kemar

Tehri Garhwal, Uttrakhand, India

bipinuniyal2511@gmail.com

Abstract

This research paper is about Grotowskis poor theatre. Before Grotowski's there were many theatre, but these theatre were not suitable for Grotowski's purpose. Before Grotowski's theatre there were Schechner's Environmental theatre, Stainslavaski's Experimental theatre, Meyerhold's Avant-grade theatre, Alexander Tiraov's Kamerney theatre, Brecht's Epic theatre, Judith Malina and Tulian Beck's Living theatre, Bread and Puppet theatre by Peter Schumana. During the 1960's a voice of deploration came by a number of persons, who demanded the abandonment of every element of the theatre borrowed from other media and not really required. This leading exponent was Jerzy Grotowski`s Poor theatre.

Keywords:- Concentrate, Experiments, Spontaneity, Institution, Exercises, Invention, Technique, Creative. 


\section{Grotowski:-}

Jerzy Grotowski was director of Polish Laboratory Theatre . Grotowski invented a theatre and called it a 'poor theatre' because he sought to eliminate all technological aids and to concentrate on the two indispensable elements: the actor and the audience. For his productions he used a space that could be rearranged to meet the specific needs of each production : make up and costumes were purely functional and no actor was permitted to change costume to indicate a change in role or psychological condition: properties were minimal and there was no scenery in the traditional sense; the actors produced all music

\section{Origin of Grotowski’s Theatre :-}

Grotowski says I am a bit impatient when asked "' what is the origin of your experimental theatre production ?' Grotowski replied that we are trying to avoid eclecticism. We are thinking about what is distinctively theatre, what separates this activity from other categories of performances and spectacle. Secondly our productions are detailed investigation of the actor- audience relationship. That is, we consider the personal and scenic technique of the actor as the core of the theatre art.(2) Grotowski has studied all the major actor - training methods such as Dullin's rhythm exercises, Delsarte's investigation of extroversive and introversive reactions. Stainslavaskis work on physical action, Meyerholds bio-mechanical training, Pekings opera, Indian Kathakali.

In Grotowskis theatre the education of actor is the elimination of his psychic process. They concentrate on the composition of roles, and construction of form. '" At the moment of psychic shock, a moment of terror of mortal danger or tremendous joy, a man does not behave naturally : A man is an elevated spiritual state uses rhythmically articulated signs, 
begins to dance, to sing. A sign, not a common gesture, is the elementary integer of expression for us..(..3..)....... we found that theatre can exist without make-up, without automatic costumes and scenography, without a separate performance area ( stage ), without lighting and sound effects, etc. It cannot exist without the actor spectator relationship of perceptual direct, live communion..... This synthetic theatre is the contemporary theatre, which we really call the Rich Theatre' - rich in flaws. (4).

Grotowski did not follow the stage and auditorium plant for each production he designed a new device for the actors and spectators. He invented many ways of actor audience relationship. Actor should build his structure among the spectators. In that references he gave the example of Byron's Cain and Kalidas's Shakuntala. Actor may ignore the spectators. We do not care lighting effects. Actor should be illuminate though the personal technique, should become a source of spiritual light. '' We abandoned make-up, fake noses, pillow- stuffed bellies- everything that the actor puts on in the dressing room before performance. We found that it was consummately theatrical for the actor to transform from type to type, character to character, silhouetie to silhoutie - while the audience watched - in a poor manner, using only his own body and craft'. (5). During Grotowski's experiment he was compelled to take a fresh look at the history of theatre in relation to other branches of knowledge. Then there was a problem myth. He clearly saw that myth was both primeval situation and a complex model.

Once theatre was parts of religion. It made free the spiritual energy of social groups by incorporating myth. Mythic forms were traditional. But in the present situation is changed. Today social groups are not defined by religion and mythic forms are disappeared from theatre. Grotowski said that Artand was an extraordinary visionary, but his work has methodological meaning because his work is not the product of investigations. Grotowski 
does not claim that everything he does is completely new. He says that he is bound by the tradition, science and arts. When we confront the general tradition of the Great Reform of the theatre from Stanislavski to Aullin and from Meyerhold to Artand. We realise that we have not started from scratch but are operating in a defiand and a special atmosphere $\mathrm{We}$ realise that theatre has certain objective laws and that fulfilment is possible only within them, or, as Thomas Mann said, through a kind of higher obedience, to which we give our dignified attention. (6). Jerzy Grotowski was the chief of Polish theatre laboratory. He was director or producer or spiritual instructor. His relation to the work is not instructive.

\section{Theatre's Element :-}

Once Naim Kattan asked some question to Grotowski, pertaining to theatre.....' You have said that the theatre can exist without costumes or scenery, without music or lighting effects and even without a text. You added : In the development of the theatrical art, the text was one of the last elements to be added. Can the producer of today disregard the theatrical tradition of several centuries? What place do you, as a producer, give to the text.' (7). 'The text is an artistic reality existing in the objective sense.' (8), said Grotowski. He says the text is a message if we find in it human experiences, human representation, illusions, myths and truths of part time and which are still actual for today. The text represent the society, it mirrors its contemporary society. In France, the text which contains dramatic theme called theatre. But Grotowski does not agree with this and called it dramatic literature.

Stainslavski's plan was to create a new kind of literary theatre, before that he wanted to know all the intentions of the dramatist. ', All the same, to put plays on stage you still have to choose texts and authors. What is your method of procedure ? How do you choose one play rather than another, or one playwright rather than another ?"” (9). In reply of this question Grotowski says that every writer and producer must seek encounters which serve his purpose 
or his own nature. Grotowski follows mostly to the text which is traditional. He says that these traditions are the voices of our great ancestors and these are the sources of European culture. Grotowski says that these books has special kind of charm of previous generation. Which fascinate me to write on the traditional matters.

Relationship Between the Dramatic work and the Age : -

Is there, in your opinion a relationship between a dramatic work and the age in which it took shape" (10). In reply of this question he says that there is indeed a relationship between the dramatic work and the age in which it took shape. But this does not decides our will to confront ourselves to these work. This is the experience which decides our work. We study the Iliad and the Odyssey nowadays, because we find these characters still actual....... art in itself, and it should not be just a duplicate of literature.

Artand also intented to finish the barrier between actors and audience or spectators. But he did not proposed to abolish the stage separate from the auditorium. He proposed to put the audience in centre and play in all four corners of the room. But this not a stage audience barrier, it is simply a replacement of the classical dolli theatre by another.

Artand's description of Balinese theatre is very attractive and suggestive. For Artand Balinese performance was like a crystal ball for a fortune - teller. ' It is the true lesson of the sacred theatre; whether we speak of the medieval European drama, the Balinese, or the Indian Kathakali; this knowledge that spontaneity and discipline far from weakening each other, mutually reinforces themselves, that what is elementary feeds what is constructed and vice versa, to become the real source of a kind of acting that glows. (11)

Artand was a prophet. He concealed such impossible allusions and visions which are very suggestive. Artand has taught a lesson of sickness. But his sickness differed from the sickness of the times. Writer and producer should not make too many contemplation in the 
field of art. Art is the experience which we take upon our selves when we presents ourselves to the others.

Grotowski’s Article About Stanislavaski and Artand :-

Jerzy Grotowski has published an article about Stanislavaski and Artand.

Stanislavaski was the first man who created the method of acting in the theatre. And in the age of Artand " Theatre of Cruelty was in order. An eminent creator Peter Brook turned to Artand. Before Artand's theory of theatre there was Brecht's theory of theatre. Many writers were in needs of confrontation, and they found it in Artand. Artand did not left any concrete technique behind him. He left only his expression of his personality. Artand also not used a good language. He used fleeting language.

Artand spoke of the magic of the theatre. He opposed the French theatre tradition, because in French theatre tradition there are digressive rules in theatre. Artand did not follow to that theatre which was based on the dramatic text, he opposed and said that theatre should be a creative. '" Actor should be like martyrs burnt alive, still signalling to us from their stakes.' (12) Artand was a great theatre poet, a man of dramatic literature. Artand is compared with prophet Issiah.

Jerzy Grotowski and Other Theories :-

An interview with Jerzy Grotowski, Danis Bablet asked him ..' I would first like you to define for me your position with regard to various acting theories as, for example, those of Stanislavaski, Artand and Brechet, explaining how, through reflection and due naturally to your personal experience, you have come to elaborate your own technique for the actor, defining both its aims and means." (13)Then Grotowski explained these theories of Artand and Brechet. Brechet explained the many interesting ways of acting with discursive 
method. Brecht explained these method from the stand point of the producer. So this was not really a method. And Artand presents an indisputable stimulate where research relative to the possibilities of the actor is concerned. Artand said that the body is the centre which decides the action and reaction of the actor. But during his research Artand escaped from the limitation of human reactions and calculated reconstruction. Stanislavaski suggested a more effective method. He was always experimenting himself.

His Position Among Other Dramatist :-

Danis Bablet again asked a question about his own position among others or these theatre dramatist. Grotowski replied that all the systems in the field of acting ask the question :- how can this be done? Grotowski believes that one must ask this question once in one's life. He again gives the example of breathing. That how should man breathe ? It is the fact that children, animals and all other creatures breathe. He says there is no perfect type of respiration valid for everyone. Breathing is a physiological reaction. He discuss about the abdominal breathing. Grotowski says "When I begin to work with an actor, the first question of ask myself is : does this actor has breathing difficulties ?" He breathes well ; he has enough air to speak, to sing. Why then creates a problem by imposing on him a different type of respiration? This would be absurd on the other hand perhaps he does have difficulties. Why are there psychical problem ? (14). We must know the actor's natural type of respiration, and we can define the factors which are obstacles in the way of natural respiration. He further pointed out the greatest dangers for the actors is his lack of disciplines. And we should never hope for any creative process if there is lack of discipline in actors. Meyerhold's work is based on discipline and Stanislavaski's is based on the spontaneity. So there are the creative process. 
Relationship Between Actor and Audience :-

The work of actor is in danger, so it is essential to give the actor security. The working system and the working place should be understood by the producer. Actor's character is always based on to the typed text which is given to the actor. Actor must not neglect the presence of audience. There is special relationship between actor and audience. Actors must present all the problems and circumstances of daily life. For Grotowski there was the most important things to search the elements of the actor's art. His theatre laboratory was built for same things.

\section{His Views About Artistic Ethic :-}

Schechner asked Grotowski about the artistic ethic and meaning of artistic life. Grotowski says that he did not use the word etihic, but indeed there was an ethical attitude. He says that during the creation if we hide something of function, resultant the creativity will face. In that case we do not present a real image of ourselves. Grotowski further emphasis on ethical problem and says we should not hide the basic things of ourselves, even if they are sins. We should completely express all these moral and immoral things which often happens with men's daily life. We should express ourselves through our own most personal motives. We should take all the risks which are the part of creative ethic. And that all is really the kernel of ethical problem.

Actor should not play for himself or for the spectator. His search must be directed from within himself to the outside. When the actor begins to penetrate through a study of his body's impulses, this process of exchange takes a rebirth in actor. Grotowski called it second rebirth of actor." Finally the actor discovers what I call the secure partner this special being in front of whom, he does everything, in front of whom he plays with the other characters and to whom reveals his most personal problems and experiences. This human being - this secure 
partner - cannot be defined. But at the moment when the actor discovers his secure partner the third and strongest rebirth occurs, a visible change in the actors behaviour.'"(15). Grotowski says that each actor should get this chance to discover within himself a secure partner, which is neither for one self and nor for spectator. It is paradoxical and it gives greatest range to actor for his greatest possibilities. Schechner asked Grotowski about the surpass yourselves and go beyond. In the reply of this question Grotowski says that actor should not stop despite fatigue. And actor should do these things which are impossible for comman man or to things that we know well we can not do. That means actor should be courageous.

\section{Secure Partner :-}

Actor to finding out his secure partner, he must be internally passive but externally active. The formula of resigning one self' not to do' is stimulus. But if actor says he to find out the' secure partner', will be very active. Grotowski says that actor should not play the text. He says that student should do their work in a peace and calm. These situation should be provided to the student. Silence is something else. External silence to the actor does the work as a stimulus. It motivates to the actor. Actor can think completely. This silence includes his thoughts. There is a problem of creative passivity. It is difficult to express but he should begin his work by doing nothing. Grotowski says that all the movement exercises, which performed by the actor had completely different function. Each movement exercises had its different works. By doing yoga, we get absolute concentration or for getting concentration we do yoga. Through yoga actor can get the power of concentration. Yoga stopped three process : thought, breathing and ejaculation. And then one finds absolute concentration. 
Jerzy Grotowski and Delsarte’s System :-

Once Grotowski was very interested in Delsarte’s system or Delsarte’s thesis of introverted and extroverted reactions in the human contact. But at the same time he find his thesis very funny. In his theory the physical exercises were largely developed by the actors. We find in his thesis how to fight, how to make unkind gestures, how to parody oneself. With these exercises we looked for a conjunction between the structure of an element and the associations which transform it into the mode of each particular actor. Grotowski made some principles for internal use of his theatre laboratory and particularly for the period of trial. The modern life is characterised by pace, tension and frustration. We became discursive and scientific. In modern civilisation man wants to hide his personal weakness. Everywhere he is getting tension. Man wants to get rid from these modern characterstics. Therefore we play a double game of intellect and instinct, thought and emotion. We want to divide ourselves into body and soul.

Theatre provides an opportunity of integration and revealing the real thing or real substances. The opportunity of integration should be treated in a disciplined manner and with a full awareness of the responsibilities. So this is the theatre's most important function. " The actor's act- discarding half measures, revealing, opening and emerging from himself as opposed to closing up - is an invitation to the spectator. This act could be compared to an act of the most deeply rooted, genuine love between two human beings - this is just a comparison since we can only refer to this emergence from oneself through analogy." (16)

It is difficult to bound the art by laws of common morality and by the catechism. The actor and creator must not be shameless. He must be a courgeous person. He has not only exhibits himself before public, but he has to reveal himself. His courage should be passive. That courage should not touch the interior sphere. It must be creative and it should reveal and purify us while we transcend ourselves. The personal sphere of actor both physical and 
spiritual must not physical and spiritual must not be swamped by trivial on mean activities.

Actor and creative person :-

The actor must be guided and inspired by the person who is whole-heartedly creative to his work. At the same time when producer guiding and inspiring to the actor, producer must allow to himself to seek inspire by him, An act of creation nothing does to working conditions of life, in which everybody is happy. This demands a maximum peaceful atmosphere and a minimum of words. A creative act is performed in group, and therefore within certain limits we should avoid our creative egoism. Private conflicts, quarrels, sentiments, animosities are unavoidable in any human or social group. So towards creation this becomes our duty to keep these activities in check, otherwise it might deform and wreck the process of creation.

In the work of each actor, order and harmony are the essential conditions. Without order and harmony a creative work cannot take place. There is a need of consistency. And this consistency is demanded from the actor. An actor must always be ready to join the creative act at the right time determined by the group. In this condition his all other activities must be stopped. We do not shirk for the sake of private happiness and then come to work tired. We must come there when we are abace to concentrate. Creativity is boundless sincerity, yet disciplined. The creator should not find his material a barrier, because actor's material is his own body. Actor should make train his body to obey. And for actor's work spontaneity and discipline are the basic aspect. " The main point then is that an actor should not try to acquire any kind of recipe or build up a box of tricks. This is no place for collecting all sorts of means of expression. The force of gravity in our work pushes the actor towards an interior ripening which expresses itself through a willingness to break through barriers, to search for a summit for totality.'(17) 
Grotowski and Bohr Institute:-

Jerzy Grotowski was influenced by the Bohr Institute. Bohr and his company established an institution. It was just like a meeting place where scientist and physicist from the different countries make experiment. In this institute these physicist compare their theories. Bohr and his company tried to find out some guiding trends for theatre and for actor. They discovered an instigation and inspiration in the share of their discipline. Jerzy Grotowski was interested in the actor because he is a human being. He searched a positive technique, creative skill for the theatre and actor. Certain exercises were retained during the training period. The actor must find out those resistances and obstacle which hinder him in the creative task. Grotowski invented such exercise which will be able to remove such obstacle from the way of actor. Most of the fundamental facts of the physical exercises have been retained. "The training consist of exercises worked out by the actors or adopted by other systems. Even those exercises which are not the result of the actor's personal research have been developed and elaborated in order to satisfy the precise aims of method"'. (18) 


\section{References}

Jerzy Grotowski - Towards a Poor Theatre, Denmark; Odin Theatre Forlag, 1968, P. 15

Ibid - P. 15

Ibid - P. 18

Ibid - P.19

Ibid - P.20

Ibid - P.24

Ibid - P.55

Ibid - P. 55

Ibid - P. 58

Ibid - P. 58

Ibid - P.121

Ibid - P.125

Ibid - P.205

Ibid - P. 208

Ibid - P.247

Ibid - P. 256

Ibid - P. 262

Ibid - P. 134 
Bibliography

Schechner, Richard - 1973, Environmental Theatre, New York, Hawthora.

Artand Antonin - 1958, The Theatre and its Double, Translated by Mary G. Richards, New York, Grove Press.

Brechet Bertolt - 1964, Brechet on Theatre, ed. John Willet, New York, Bill and Wang. Brockett Oscar G. - 1980, The Essential Theatre Ind ed., New York, Holt Rinechart and Winston.

Grotowski Jerzy - 1968, Towards a Poor Theatre, Holstebro, Denmark, Odin Theatre Forlag. Shank Theodre - 1982, American Alterative Theatre, New York, Grove Press.

Meyerhold Vsevolod Emilevich - 1969, Meyerhold on Theatre, Trans. And ed. Edward Braien, New York, Hill and Wang.

Stanislavaski Constantin - 1946, An Actor Prepares, New York, Theatre Arts Book. 